\title{
KEDUDUKAN HUKUM APARATUR PENGAWASAN INTERN PEMERINTAH DALAM PENGAWASAN PENGADAAN BARANG/ JASA PEMERINTAH
}

\author{
Muhammad Nur Aflah, Muhammmad Junaidi, Zaenal Arifin, Kadi Sukarna \\ Magister Hukum Universitas Semarang, Semarang \\ floh_pidkorjtg@yahoo.com
}

\begin{abstract}
Abstrak
Artikel ini bertujuan mengkaji dan menganalisa kedudukan Aparatur Pengawasan Intern Pemerintah (APIP) serta kendala dan solusi atas kedudukan APIP dalam pengawasan pengadaan barang/jasa berdasarkan Perpres 16 Tahun 2018. Pada tahun 2018, telah disahkan Perpres 16 Tahun 2018 tentang pengadaan barang/jasa pemerintah. Diantara yang diatur adalah penanganan pengaduan masyarakat dalam pengawasan pengadaan barang/jasa pemerintah yang seolah-olah mendegradasi kewenangan Aparat Penegak Hukum (APH), khususnya penegakan hukum terhadap tindak pidana korupsi. Urgensi penelitian ini ialah diharapkan dapat menegaskan perbedaan antara indikasi tindak pidana dengan kesalahan administrasi. Penelitian ini menggunakan pendekatan yuridis normatif dengan jenis deskriptif analitis. Kewenangan APIP didefinisikan sebagai menerima pengaduan, menindaklanjuti, dan melaporkan. Kendala dan solusi dibagi menjadi 3 subsistem. Pada legal substance belum adanya pengaturan yang merumuskan peran APIP dan adanya pengaturan yang tidak memberi ruang kepada APH dalam pengawasan pengadaan. Solusinya perlu revisi Perpres yang mengatur peran APIP serta menghilangkan aturan yang membatasi ruang APH dalam pengawasan. Dari sisi legal structure, 2 kendala berupa struktur organisasi dan sistem kerja. Solusinya, perlu adanya komite audit yang independen serta sistem pengembangan karier dengan motivasi mutasi. Terakhir dari sisi legal culture, kedudukan APIP menyisakan problematika paradigma kerja individu dan organisasi yang terkesan reaktif. Solusinya APIP perlu merevitalisasi pola pikir serta membutuhkan mitra kerja yang mampu merumuskan tindakan preemtif dan preventif.
\end{abstract}

Kata kunci: Kedudukan; Pengadaan Barang/Jasa; Pengawasan Internal

\section{LEGAL POSITION OF INTERNAL SUPERVISION APPARATUS GOVERNMENT IN PROCUREMENT SUPERVISION GOVERNMENT GOODS/SERVICES}

\begin{abstract}
This article aims to examine and analyze the position of Aparatur Pengawasan Intern Pemerintah (APIP) as well as the obstacles and solutions to the position of APIP in supervising the procurement of goods/services based on Presidential Regulation 16 of 2018. In 2018, Presidential Decree 16 of 2018 has been ratified regarding government procurement of goods/services. Among those regulated is the handling of public complaints in the supervision of the procurement of government goods/services which seems to degrade the authority of Aparat Penegak Hukum (APH), especially law enforcement against corruption. The urgency of this research is that it is hoped that it can confirm the difference between indications of a criminal act and an administrative error. This study uses a normative juridical approach with analytical descriptive type. APIP's authority is defined as receiving complaints, following up, and reporting. Constraints and solutions are divided into 3 subsystems. In legal substance there is no regulation that formulates the role of APIP and there are regulations that do not provide space for APH in procurement supervision. The solution requires a revision of the Presidential Regulation that regulates the role of APIP and eliminates the rules that limit APH's space in supervision. In terms of Legal Structure, 2 obstacles are organizational structure and work system. The solution is to have an independent audit committee and a career development system with a transfer motivation. Finally, in terms of legal culture, APIP's position leaves problematic individual and organizational work paradigms that seem reactive. The solution is that APIP needs to revitalize the mindset and needs partners who are able to formulate pre-emptive and preventive actions.
\end{abstract}

Keywords: Position; Procurement of Goods/Services; Internal Monitoring 


\section{A. PENDAHULUAN}

Terciptanya pemerintahan yang bersih dan berwibawa merupakan hal yang sangat urgen. Untuk mewujudkannya diperlukan pengelolaan berbagai bidang kehidupan seperti politik, hukum, ekonomi, sosial dan budaya secara lebih serius, transparan, dan terarah serta melibatkan semua komponen bangsa guna bersamasama bangkit dari keterpurukan dan kehinaan di mata dunia internasional. ${ }^{1}$ Salah satu upaya pemerintah ialah dengan membuat UU Nomor 30 Tahun 2014 tentang Administrasi Pemerintahan dan UU Nomor 23 Tahun 2014 tentang Pemerintah Daerah menjadi langkah awal memajukan tugas dan kapasitas Aparatur Pengawasan Intern Pemerintah (selanjutnya disebut APIP). Peran APIP diharapkan menjamin penyelenggaraan urusan pemerintahan daerah dilaksanakan secara tertib, efisien, efektif sesuai dengan rencana dan ketentuan peraturan perundang-undangan serta mendorong terwujudnya pemerintahan yang baik, bersih dan berwibawa, bebas dari penyimpangan dan peyalahgunaan kekuasaan serta $\mathrm{KKN} .^{2}$

Pada 28 Februari 2018, Kementerian Dalam Negeri, Polri (melalui Badan Reserse Kriminal Polri) dan Kejaksaan Agung menandatangani Perjanjian Kerja Sama tentang APIP dengan APH terkait Penanganan Laporan atau Pengaduan Masyarakat dalam Penyelenggaraan Pemerintahan Daerah. Perjanjian ini dimaksudkan sebagai pedoman operasional bagi para pihak dalam melakukan koordinasi penanganan laporan masyarakat yang berindikasi tindak pidana korupsi serta memperkuat sinergitas kerjasama APIP dan Aparat Penegak Hukum (APH). ${ }^{3}$ Ruang lingkup kerja sama tersebut meliputi; tukar menukar informasi, mekanisme penanganan laporan dan peningkatan kapasitas SDM. Poin pentingnya, APIP dan APH menindaklanjuti laporan masyarakat sesuai kewenangannya. Jika ditemukan indikasi tindak pidana korupsi, APIP menyerahkan kepada APH guna dilakukan proses penyelidikan.

Berdasarkan ketentuan Peraturan Pemerintah Nomor 60 Tahun 2008 tentang Sistem Pengendalian Intern Pemerintah, APIP berwenang dan berkedudukan sebagai pelaksana pengawas intern pemerintah yang meliputi seluruh proses kegiatan audit, review, evaluasi, pemantauan, dan kegiatan pengawasan lain. ${ }^{4}$ Pada tahun 2018 terbit peraturan perundang-undangan yaitu Perpres No. 16 Tahun 2018 tentang Pengadaan Barang/Jasa Pemerintah sebagai pengganti Perpres 54 Tahun 2010, yang juga menempatkan APIP sebagai pihak yang melakukan pengawasan pada proses pengadaan barang/jasa pemerintah. Sebagaimana dimaksudkan dalam

\footnotetext{
${ }^{1}$ Yunus Nur Rohim, "Menciptakan Good and Clean Government Berbasis Syariah Islamiyah dalam Tatakelola Pemerintahan Republik Indonesia,” Jurnal Nur El-Islam 3, no. 1 (2016): 143.

${ }^{2}$ Yohanes Elieser, "Peran Aparat Pengawas Intern Pemerintah (APIP) dalam Penyelenggaraan Pemerintahan Daerah di Kabupaten Bulungan,” Jurnal Paradigma 7, no. 2 (2018): 66.

${ }^{3}$ Pasal 2 Perjanjian Kerja Sama Kementrian Dalam Negeri, Kejaksaan Republik Indonesia, Kepolisian Negara Republik Indonesia tentang tentang Koordinasi Aparat Pengawas Internal Pemerintah (APIP) dengan Aparat Penegak Hukum (APH) Terkait Penanganan Laporan atau Pengaduan Masyarakat dalam Penyelenggaraan Pemerintahan Daerah.

4 Pasaribu, Pramella Yunidar dan Briando, Bobby, "Internalisasi Nilai-Nilai Pancasila Dalam Penyusunan Kode Etik Aparatur Pengawas Internal Pemerintah (APIP)," Jurnal Ilmiah Kebijakan Hukum 13, no. 2 (2019): 247.
} 
ketentuan umum Pasal 1 angka 22 Perpres 16 Tahun 2018, APIP adalah aparat yang melakukan pengawasan melalui audit reviu, pemantauan, evaluasi, dan kegiatan pengawasan lain terhadap penyelenggaraan tugas dan fungsi pemerintah. Pengadaan barang/jasa sebagaimana diatur dalam Pasal 4 Perpres Nomor 16 Tahun 2018, mempunyai tujuan: ${ }^{5}$

a. menghasilkan barang/jasa yang tepat dari setiap uang yang dibelanjakan, diukur dari aspek kualitas, jumlah, waktu, biaya, lokasi dan penyedia;

b. meningkatkan penggunaan produk dalam negeri;

c. meningkatkan peran serta Usaha Mikro, Usaha Kecil dan Usaha Menengah;

d. meningkatkan peran pelaku usaha nasional;

e. mendukung pelaksanaan penelitian dan pemanfaatan barang/jasa hasil penelitian;

f. meningkatkan keikutsertaan industri kreatif;

g. mendorong pemerataan ekonomi; dan mendorong pengadaan berkelanjutan.

Pengadaan barang dan jasa pemerintah merupakan aktivitas yang sangat penting dalam mewujudkan pembangunan. ${ }^{6}$ Namun dalam kegiatan pengadaan barang/jasa rawan penyimpangan bukan saja oleh pelaku pengadaan itu sendiri tetapi juga oleh pihak yang mempunyai kewenangan secara struktural sebagai pengguna barang/jasa yang mengintervensi pelaku pengadaan untuk kepentingan pribadi maupun kelompoknya. Dalam laporan KPK tahun 2018, jenis perkara korupsi pengadaan barang/jasa menempati peringkat kedua dari keseluruhan perkara korupsi. ${ }^{7}$ Adapun pada pasal 76 Perpres 16 Tahun 2018 dengan jelas mengatur adanya kewajiban pengawasan pada pelaksanaan pengadaan barang/jasa pemerintah oleh menteri/kepala lembaga/kepala daerah melalui audit review, pemantauan, evaluasi, dan kegiatan pengawasan lain oleh APIP. Senada dengan perjanjian kerja sama tiga kementerian dan lembaga yang mengatur mekanisme laporan/pengaduan dari masyarakat, Perpres 16 Tahun 2018 juga mengatur mekanisme laporan/pengaduan masyarakat, bedanya APH tidak diatur lebih lanjut untuk menindaklanjuti pengaduan masyarakat melainkan meneruskan pengaduan tersebut kepada APIP untuk ditindaklanjuti. Ketentuan tersebut seolah mengesampingkan kompetensi APH dalam menentukan ada tidaknya KKN, sementara APIP sebagaimana fungsinya sebatas auditor.

Secara kelembagaan APIP adalah salah satu perangkat pemerintah (eksekutif) sehingga dalam ilmu ketatanegaraan berdiri mewakili lembaga negara yang bernama ekskutif. Sedangkan APH, yaitu kepolisian dan kejaksaan, meski secara

\footnotetext{
Pemerintah.

${ }^{5}$ Peraturan Presiden Republik Indonesia Nomor 16 Tahun 2018 tentang Pengadaan Barang/Jasa

${ }^{6}$ Muhammad Iqbal, "Pengaruh Pelaksanaan E Katalog dalam Pengadaan Barang/Jasa Pemerintah terhadap UMKM," Jurnal USM Law Review 3, no. 1 (2020): 79.

${ }^{7}$ Laporan Tahunan Komisi Pemberantasan Korupsi, 2018.
} 
kelembagaan berada pada jajaran lembaga eksekutif, namun dalam menjalankan fungsinya berada pada jajaran lembaga yudikatif. Lembaga eksekutif dan lembaga yudikatif dalam suatu negara yang menganut konsep trias politica tidak boleh saling mengintervensi maupun mempengaruhi, karena satu sama lain adalah pembatas bagi kekuasaannya agar tidak sewenang-wenang. Dengan adanya ketentuan APH menyerahkan laporan/aduan masyarakat kepada APIP sebagaimana diatur pada Pasal 77 Perpres 16 Tahun 2018 seolah telah mengesampingkan prinsip pemisahaan kekuasaan (konsep trias politica), karena memunculkan intervensi dan tumpang tindih kewenangan eksekutif melalui APIP terhadap lembaga yudikatif yakni APH. Permasalahan yang lain adalah mengenai sejauh mana kompetensi dan kedudukan APIP dalam pengawasan pengadaan barang/jasa.

Penelitian terdahulu dan relevan dengan artikel ini pernah dilakukan oleh Marliani et al (2018) menekankan pada efektifitas penggunaan metode, pendekatan, dan fokus audit oleh inspektorat dan aspek yang menjadi kendala dalam implementasi penguatan peran APIP. ${ }^{8}$ Metode penelitian adalah kualitatif. Hasil dari penelitian menunjukkan bahwa metode, pendekatan dan fokus audit yang seharusnya dilakukan dalam paradigma baru, belum berubah secara keseluruhan. Implementasi penguatan peran APIP juga memiliki beberapa kendala diantaranya, kompetensi sumber daya manusia para auditor, jumlah anggaran relatif kecil, lemahnya independensi, objekvitas auditor masih kurang, dan komitmen dari stakeholder belum maksimal.

Penelitian Alfianto (2019), ${ }^{9}$ artikelnya lebih berfokus pada aspek hukum pengadaan barang dan jasa yang menimbulkan kerugian negara serta bagaimana peran dan wewenang APIP dalam pencegahan perbuatan pidana korupsi pada aspek penyediaan barang maupun jasa di sektor publik untuk mewujudkan good governance. Hasil penelitian menunjukkan, berlakunya UU Nomor 31 Tahun 1999 yang diperbaharui dengan UU Nomor 20 Tahun 2001, maka perbuatan menerima hadiah, fee atau komisi, mengumpulkan dana, dapat diklasifikasikan sebagai perbuatan korupsi. Pada ketentuan yang dimuat di dalam Bab II UU tindak pidana korupsi, terdapat 19 pasal beberapa perbuatan yang bisa diklasifikasikan sebagai perbuatan tindak pidana korupsi. Kemudian dalam penelitiannya tidak ditemukan APIP berperan mengurangi korupsi di wilayah pemerintah sejauh ini. Maka dari itu APIP perlu menciptakan early warning system terhadap tahap-tahap penyediaan barang atau jasa.

\footnotetext{
${ }^{8}$ Marliani et al, "Evaluasi Efektivitas Penguatan Peran Aparat Pengawasan Intern Pemerintah dalam Paradigma Baru (Studi Kasus pada Salah Satu Inspektorat di Aceh)," Jurnal Perspektif Ekonomi Darussalam 4, no. 1 (2018): 95-108.

9 Alfianto, Dwi, "Peran Aparat Pengawas Intern Pemerintah (APIP) untuk Mewujudkan Good Governance dalam Pencegahan Tindak Pidana Korupsi di Bidang Penyediaan Barang dan Jasa," Jurnal Hukum Pidana dan Pembangunan Hukum 1, no. 2 (2019): 1-9.
} 
Penelitian terdahulu oleh Lumempouw et al (2021), ${ }^{10}$ artikelnya berfokus kepada peran aparatur APIP dalam mencegah dan mendeteksi kecurangan serta mengidentifikasi permasalahan yang dihadapi inspektorat dalam mencegah dan mendeteksi kecurangan biaya perjalanan dinas. Penelitian ini menggunakan metode kualitatif, dengan pendekatan studi kasus. Analisis data menggunakan model analisis data Miles dan Huberman (1984). Hasil penelitian mengungkapkan bahwa Inspektorat Daerah Sulut telah efektif menjalankan peran APIP sebagai assurance dan konsultan dalam mencegah dan mendeteksi kecurangan biaya perjalanan dinas. Namun, berdasarkan laporan temuan audit Badan Pemeriksa Keuangan (BPK) wilayah Sulut tahun 2018 dan 2019, terdapat temuan terkait penyalahgunaan biaya perjalanan dinas. Permasalahan yang dihadapi inspektorat dalam mencegah dan mendeteksi kecurangan biaya perjalanan dinas, yaitu: 1) Keterbatasan waktu, sumber daya manusia. dan anggaran; 2) Kurangnya partisipasi auditee dalam audit; 3) Kurangnya pemahaman tentang audit berbasis risiko; dan 4) Unit konsultasi belum terbentuk.

Perbedaan penelitian ini dengan penelitian terdahulu adalah kedudukan APIP dan APH dalam penerimaan pengaduan masyarakat tentang pengadaan barang/jasa pemerintah pada Pasal 77 Perpres 16 tahun 2018 tentang Pengadaan Barang/Jasa Pemerintah yang memunculkan intervensi kewenangan eksekutif melalui APIP terhadap lembaga yudikatif yakni Aparat Penegak Hukum (APH). Adapun kelebihan penelitian ini ialah bagaimana upaya peningkatan kompetensi APIP sebagai tim investigasi penyimpangan pengadaan barang/jasa menggunakan perspektif sistem hukum yang diterangkan oleh Lawrence M. Friedman yang terdiri dari legal substance (substansi hukum), legal structure (struktur hukum) dan legal culture (budaya hukum). ${ }^{11}$ Berdasarkan paparan pendahuluan di atas, maka artikel ini bertujuan untuk mengkaji dan menganalisis kedudukan APIP serta kendala dan solusi atas kedudukan APIP dalam pengawasan pengadaan barang/jasa berdasarkan Perpres 16 Tahun 2018.

\section{B. PERMASALAHAN}

Berdasarkan uraian latar belakang di atas, rumusan masalah yang akan dibahas dalam artikel ini adalah:

1. Bagaimana kedudukan APIP dalam pengawasan pengadaan barang/jasa pemerintah berdasarkan Perpres No. 16 Tahun 2018 tentang Pengadaan Barang/Jasa Pemerintah?

2. Bagaimana kendala dan solusi atas kedudukan APIP dalam pengawasan pengadaan barang/jasa pemerintah berdasarkan Pasal 77 Perpres No. 16 Tahun 2018 tentang Pengadaan Barang/Jasa Pemerintah?

\footnotetext{
${ }^{10}$ Lumempouw, Eliska Gricy et al, “Analisis Peran Aparat Pengawas Internal Pemerintah (Apip) dalam Pencegahan dan Pendeteksian Fraud Biaya Perjalanan Dinas (Studi Kasus Pada Inspektorat Daerah Provinsi Sulawesi Utara)," Jurnal Riset Akuntansi dan Auditing “Goodwill” 12, no. 2 (2021): 252-263.

11 Yuliana, "Dampak Pelaksanaan Hukuman Mati terhadap Kondisi Kejiwaan Terpidana Mati di Indonesia,” Indonesian Journal Of Criminal Law Studies 1, no. 1 (2016): 48.
} 


\section{METODE PENELITIAN}

Pendekatan yang dilakukan dalam penelitian ini adalah yuridis normatif atau pendekatan hukum doktrinal. Menurut Sunggono dalam Benuf dan Azhar, pendekatan yuridis normatif merupakan suatu pendekatan yang mengacu pada hukum dan peraturan perundang-undangan yang berlaku. ${ }^{12}$ Pendekatan undangundang dilakukan dengan menganalisis semua UU dan regulasi yang memiliki hubungan dengan permasalahan hukum yang diteliti mengenai kedudukan APIP secara umum dan secara khusus dalam pengawasan pengadaan barang/jasa pemerintah. Untuk lebih menekankan pada permasalahan yang akan diteliti maka digunakan spesifikasi penelitian deskriptif analitis. Penelitian deskriptif analitis adalah suatu metode yang berfungsi untuk mendeskripsikan atau memberi gambaran terhadap objek yang diteliti melalui data atau sampel yang telah terkumpul sebagaimana adanya tanpa melakukan analisis dan membuat kesimpulan yang berlaku untuk umum. $^{13}$ Kemudian Zellatifanny dan Mudjiyanto menambahkan penelitian deskriptif bertujuan menggambarkan fakta secara sistematis dan karakteristik objek serta frekuensi yang diteliti secara tepat. ${ }^{14}$

Dalam penelitian hukum dengan pendekatan yuridis normatif, jenis data yang digunakan dalam penelitian ini adalah data sekunder sebagai norma hukum melalui serangkaian kegiatan membaca, menelaah, menganalisa, mengutip perundangundangan serta melakukan studi perpustakaan (library research) yang berkaitan dengan permasalahan yang dikaji. Data sekunder merupakan data yang diperoleh melalui studi kepustakaan yang bersumber dari buku-buku, jurnal, artikel, dan penelitian terdahulu. ${ }^{15}$ Kemudian Mardalis dalam Milya studi kepustakaan merupakan studi yang digunakan dalam mengumpulkan informasi dan data dengan bantuan berbagai macam material yang ada di perpustakaan seperti dokumen, buku, majalah, kisah-kisah sejarah. ${ }^{16}$ Muhadjir dalam Ahmad mengemukakan pengertian analisis data sebagai "upaya mencari dan menata secara sistematis catatan hasil observasi, wawancara, dan lainnya untuk meningkatkan pemahaman peneliti tentang kasus yang diteliti dan menyajikannya sebagai temuan bagi orang lain. ${ }^{17}$ Sedangkan untuk meningkatkan pemahaman tersebut analisis perlu dilanjutkan dengan berupaya mencari makna. Untuk menganalisis bahan hukum yang terkumpul, dalam penelitian ini menggunakan metode analisis data kualitatif, dimana data-data yang telah diperoleh dan telah disusun secara sistematis,

12 Benuf, Kornelius, dan Azhar, Muhamad, "Metodologi Penelitian Hukum sebagai Instrumen Mengurai Permasalahan Hukum Kontemporer," Jurnal Gema Keadilan 7, no. 1 (2020): 24.

${ }^{13}$ Sugiyono, Metode Penelitian Kuantitatif Kualitatif dan R \& D, (Bandung: Alfabeta, 2009), 29.

14 Zellatifanny, Cut Medika dan Mudjiyanto, Bambang, "Tipe Penelitian Deskripsi dalam Ilmu Komunikasi,” Jurnal Diakom 1, no. 2 (2018): 83.

${ }^{15}$ Bajuri, Diding, "Analisis Kualitas Pelayanan Publik Perangkat Desa Pagandon Kecamatan Kadipaten Kabupaten Majalengka," Jurnal Ilmu Administrasi Negara 4, no. 1 (2013): 185.

${ }^{16}$ Sari, Milya, "Penelitian Kepustakaan (Library Research) dalam Penelitian Pendidikan IPA," Jurnal Penelitian Bidang IPA dan Pendidikan IPA 6, no. 1 (2020): 43.

${ }^{17}$ Ahmad, Rijali, “Analisis Data Kualitatif,” Jurnal Alhadharah 17, no. 33 (2018): 84. 
selanjutnya akan dianalisis. Analisis kualitatif merupakan suatu tata cara penelitian yang menghasilkan data deskriptif analisis.

\section{HASIL DAN PEMBAHASAN}

\section{Kedudukan APIP dalam Pengawasan Pengadaan Barang/Jasa Pemerintah berdasarkan Perpres No. 16 Tahun 2018}

Penyaluran dan pendistribusian anggaran belanja negara salah satunya melalui pengadaan barang/jasa pemerintah. Pengadaan barang/jasa pemerintah merupakan komponen fundamental dari tata kelola pemerintahan yang baik (good governance). Pengadaan barang/jasa pemerintah memiliki tujuan antara lain memperoleh barang/jasa dengan harga yang dapat dipertanggung jawabkan dengan jumlah dan mutu sesuai serta tepat waktu pelaksanannya.Untuk mengatur pelaksanaan pengadaan barang/jasa yang dibiayai dari APBN/APBD perlu diatur dari sisi formal maupun material. Mengingat pembiayaan pengadaan barang/jasa pemerintah merupakan belanja pemerintah yang menggunakan keuangan negara yang antara lain bersumber dari pajak setiap warga negara Indonesia. Pengaturan tersebut dimaksudkan agar proses pengadaan barang dan jasa memiliki akuntabilitas dan tanpa mengurangi efektifitas dalam pelaksanaannya. ${ }^{18}$

Landasan utama Perpres No 16 Tahun 2018 berperan strategis untuk peningkatan pelayanan publik dan pengembangan perekonomian nasional dan daerah. Pertimbangan lainnya bahwa untuk mewujudkan pengadaan barang/jasa pemerintah sebagaimana disebut sebelumnya, perlu pengaturan yang memberikan pemenuhan nilai manfaat yang sebesar-besarnya dan kontribusi dalam peningkatan penggunaan produk dalam negeri, peningkatan peran usaha mikro, usaha kecil, dan usaha menengah serta pembangunan berkelanjutan.

Asas value for money bertujuan penggunaan uang seberapapun harus dijamin adanya manfaat sebesar-besarnya. Perekonomian nasional tidak mungkin tumbuh jika tidak didukung oleh produktivitas sektor usaha, salah satunya adalah produk dalam negeri. Guna membuka ruang suplai terhadap produk (barang/jasa) dalam negeri maka sektor usaha dalam negeri ditingkatkan dengan cara dibuka peluang suplai ke pemerintah, yaitu dengan adanya demand dari pemerintah dalam hal pengadaan barang/jasa. Prinsip value for money menjadi tujuan pertama dari kebijakan dalam Perpres No 16 Tahun 2018. Tujuan kedua berkaitan dengan penggunaan produk dalam negeri. Tujuan ketiga berhubungan dengan pilar ekonomi UMKM. Tujuan keempat berhubungan dengan peran pelaku usaha nasional. Tujuan kelima adalah pemanfaatan produk baik barang maupun jasa hasil penelitian. Tujuan keenam, ialah mendorong industri kreatif berkiprah dalam roda ekonomi nasional. Terakhir tujuan ketujuh, merupakan ketuntasan dalam mata rantai pasokan pengadaan barang dan jasa yaitu pengadaan yang berkelanjutan. Melalui tujuan ini, diharapkan adanya kesinambungan jalur pasokan sehingga perekonomian terus bergerak dan berkembang.

${ }^{18}$ Arifin, Zaenal, “Tindak Pidana Korupsi Pengadaan barang dan Jasa Pemerintah” Jurnal Responsif 5, no. 5 (2017): 55 . 
Prepres No 16 Tahun 2018 memuat aturan atau pedoman pengadaan barang/jasa pemerintah dalam Bab XII Pengawasan, Pengaduan, Sanksi, dan Pelayanan Hukum. Selain itu APIP sebagai aparat yang melakukan pengawasan melalui audit, reviu, pemantauan, evaluasi, dan kegiatan pengawasan lain terhadap penyelenggaraan tugas dan fungsi pemerintah. Kegiatan pengawasan dapat berupa kegiatan audit, review, pemantauan, evaluasi, dan/atau penyelenggaraan whistle blowing system.

Perpres tidak mengatur lebih lanjut mengenai peran dan perlibatan APIP dalam setiap proses pengadaan barang/jasa termasuk akses APIP atas laporan hasil pengadaan. Kedudukan APIP sebagai pengawas internal dalam pengadaan barang/jasa menjadi sebatas slogan saja tanpa adanya mekanisme aksi yang bisa dilaksanakan oleh APIP sebagai pengawas pengadaan barang/jasa. Hal tersebut memperkuat penelitian terdahulu yang dilakukan oleh Alfianto (2019), dalam penelitiannya tidak ditemukan APIP berperan mengurangi korupsi di wilayah pemerintah sejauh ini. Pasal 77 Perpres No 16/2018 mengatur kewenangan APIP sebagai berikut:

(1) Masyarakat menyampaikan pengaduan kepada APIP disertai bukti yang faktual, kredibel, dan autentik.

(2) Aparat Penegak Hukum meneruskan pengaduan masyarakat kepada APIP untuk ditindaklanjuti.

(3) APIP sebagaimana dimaksud pada ayat (1) dan ayat (2) menindaklanjuti pengaduan sesuai kewenangannya.

(4) APIP melaporkan hasil tindak lanjut pengaduan kepada menteri/kepala lembaga/kepala daerah.

Secara garis besar, sub bab pengaduan masyarakat dalam Perpres No 16 Tahun 2018 terdiri dari tujuh ayat yang merupakan urutan langkah dalam merespons pengaduan masyarakat terkait pengadaan barang dan jasa pemerintah. Ayat ke (1) sampai ke (4) merupakan hulu dari proses pengaduan, diatur bahwa baik masyarakat maupun APH dapat dalam memberikan input pengaduan melalui kewenangan yang dimiliki oleh APIP. Selanjutnya APIP bertanggung jawab dalam memproses tindak lanjut pengaduan tersebut, sebagai ujung dari kewenangan APIP adalah melaporkan hasil tindak lanjut kepada kepala kementerian/kepala lembaga/kepala daerah.

Aturan dalam pasal 77 ayat (5) Perpres No 16 Tahun 2018 mengatur tentang tindak lanjut laporan dalam hal diyakini adanya indikasi KKN yang merugikan keuangan negara, kepada instansi yang berwenang. Ayat ke (6) mengatur tentang peran menteri/kepala lembaga/kepala daerah dalam memfasilitasi pengawasan masyarakat pada pengadaan barang/jasa pemerintah. Ayat ke (7) mengatur tentang Lembaga Kebijakan Pengadaan Barang/Jasa Pemerintah yang selanjutnya disingkat LKPP. 
Dengan demikian sub bab pengaduan masyarakat yang diatur dalam Perpres Nomor 16 Tahun 2018 jika diskemakan menjadi, sebagai berikut:

1. Aturan pada ayat ke (1) sampai dengan ayat ke (4) mengatur tentang peran atau kedudukan APIP dalam hal merespons pengaduan dari masyarakat dan APH. Kegiatan utama APIP menerima pengaduan yang disertai dengan bukti yang faktual, kredibel, dan autentik. Selanjutnya APIP berwenang menindaklanjuti boleh jadi memverifikasi alat bukti dan keterangan pengaduan tersebut dalam ruang lingkup fungsi pengawasan yang dijamin oleh peraturan perundang-undangan. Terakhir, menyerahkan laporan tindak lanjut pengaduan masyarakat kepada kepala kementerian/kepala lembaga/kepala daerah.

2. Aturan pada ayat ke (5) Pasal 77 Perpres No 16/2018 berisi kewenangan kepala kementrian/kepala lembaga/kepala daerah menindaklanjuti pengaduan masyarakat yang beraroma KKN kepada instansi yang berwenang.

3. Ayat ke (6) mengatur tentang kewenangan kepala kementerian/kepala lembaga/kepala daerah memfasilitasi pengawasan bersama masyarakat.

4. Ayat ke (7) mengatur kewenangan Lembaga Kebijakan Pengadaan Barang/Jasa Pemerintah dalam mengembangkan sistem pengaduan masyarakat.

Sistem pengaduan masyarakat telah menjadi rumusan peraturan perundangundangan sejak lama. Sebagaimana formulasi penanganan pengaduan masyarakat berikut ini :

Prinsip penanganan pengaduan masyarakat ini merupakan nilai dasar yang wajib dipedomani oleh setiap instansi pemerintah dalam menangani pengaduan masyarakat. Adapun prinsip-prinsip tersebut adalah:

1) Obyektivitas, bahwa kegiatan penanganan pengaduan masyarakat harus berdasarkan fakta atau bukti yang dapat dinilai berdasarkan kriteria tertentu yang ditetapkan

2) Koordinasi, bahwa kegiatan penanganan pengaduan masyarakat harus dilaksanakan dengan kerjasama yang baik antar pejabat yang berwenang dan terkait berdasarkan mekanisme, tata kerja dan prosedur yang berlaku, sehingga masalahnya dapat diselesaikan sebagaimana mestinya

3) Efektivitas dan efisiensi, bahwa kegiatan penanganan pengaduan masyarakat harus dilaksanakan secara tepat sasaran, hemat tenaga, waktu dan biaya

4) Akuntabilitas, bahwa proses kegiatan penanganan pengaduan masyarakat dan tindak lanjutnya harus dapat dipertanggungjawabkan kepada masyarakat sesuai dengan ketentuan peraturan perundang-undangan dan prosedur yang berlaku 
5) Kerahasiaan, bahwa penanganan terhadap suatu pengaduan masyarakat dilakukan secara hati-hati dan dijaga kerahasiaannya sesuai dengan ketentuan peraturan perundang-undangan yang berlaku

6) Transparan. bahwa hasil kegiatan penanganan pengaduan masyarakat diformasikan berdasarkan mekanisme dan prosedur yang jelas dan terbuka, sesuai dengan ketentuan peraturan perundang-undangan yang berlaku

Kedudukan APIP sangat strategis dalam menerima pengaduan karena partisipasi masyarakat merupakan modal dasar pengawasan bersama Aparat Sipil Negara (ASN) dalam memandang penyelenggaraan good and clean governance. Partisipasi masyarakat, adalah peran aktif masyarakat untuk ikut serta mewujudkan penyelenggara negara yang bersih dan bebas dari KKN, yang dilaksanakan sesuai dengan norma hukum, nilai moral, sosial dan budaya yang berlaku dalam masyarakat. Berbasis pada mens rea masyarakat tersebut maka pengaduan masyarakat merupakan input awal yang bernilai yang oleh Perpres No 16/2018 menjadi kewenangan APIP untuk memprosesnya.

Kewenangan APIP dalam domain pengawasan, lebih detail diatur dalam Peraturan Menteri Dalam Negeri Republik Indonesia Nomor 35 Tahun 2018 tentang Kebijakan Pengawasan Penyelenggaraan Pemerintahan Daerah tahun 2019. Kebijakan Pengawasan Penyelenggaraan Pemerintahan Daerah Tahun 2019 sebagaimana dimaksud dalam Pasal 2, disusun berbasis prioritas dan risiko dengan tema APIP bekerja mencegah korupsi. Sementara itu dalam bidang pengadaan barang/jasa pemerintah, diatur bahwa dalam fokus pengawasan pengadaan barang dan jasa, meliputi:

a. perencanaan pengadaan barang dan jasa;

b. implementasi e-procurement dan e-katalog; dan

c. kelembagaan Unit Layanan Pengadaan (ULP).

Kata kunci pengawasan berbasis risiko menunjukkan peran strategis berikutnya bagi APIP. Manajemen risiko pada dasarnya, bagaimana meletakan risiko ke dalam dasar agar tidak muncul di daerah ambang. Selanjutnya diupayakan sedemikian sehingga jika muncul di daerah ambang, diikhtiarkan tidak muncul di permukaan aktual. Sehingga manajemen risiko perlu mitigasi terhadap risiko tersebut jika benar-benar muncul menjadi kekuatan aktual yang dapat membahayakan ekonomi atau kerugian negara. Oleh karena itu tindakan preemtif menekan risiko tidak keluar ke area ambang. Kemudian tindakan preventif menekan potensi risiko tidak keluar ke permukaan menjadi kekuatan aktual yang merugikan ruang lingkup pengawasan. Untuk itu dalam pendekatan pencegahan kebocoran keuangan negara dalam konteks pengadaan barang dan jasa pemerintah APIP melakukan tindakan seperti bimbingan teknis pemeriksaan investigatif, bimbingan teknis pendampingan pengadaan barang dan jasa (probity advice) dan bimbingan teknis penerapan sistem manajemen risiko. 
Upaya untuk menjamin pencapaian tujuan organisasi melalui tiga komponen utama yang saling terkait. Pertama, governance yaitu struktur dan proses yang digunakan manajemen untuk menginformasikan, mengarahkan, mengelola dan memantau kegiatan organisasi untuk mencapai tujuan. Dan memanfaatkan peluang untuk keberhasilan organisasi. Nampak bahwa skema di atas menerangkan tentang tiga komponen utama dalam menuju cita-cita organisasi melalui fungsi manajemen risiko. Menurut Angelica et al, tiga komponen dalam manajemen risiko meliputi First Line of Defense, Second Line of Defense, dan Third Line of Defense. ${ }^{19}$

Peran APIP, terumuskan dalam beberapa tugas utama dalam sebuah manajemen risiko, diantaranya:

\section{1) First Line of Defense}

Peran pertama pada dimensi operasi bisnis, yaitu berfungsi menjalankan operasi, manajemen risiko dan pengendalian.

\section{2) Second Line of Defense}

Peran kedua pada dimensi fungsi pengawasan, yaitu berfungsi menetapkan dan memonitor implementasi kebijakan dan standar manajemen risiko.

3) Third Line of Defense

Peran ketiga pada dimensi internal audit yaitu berfungsi memberi jaminan dan saran di bidang Governance, Risk Management dan Compliance (GRC). Dengan demikian APIP berperan cukup signifikan karena fungsi pengaman di tiga dimensi yang strategis pada skema manajemen risiko di organisasi. Sebut saja UU No. 23 Tahun 2014 pasal 385 mengatur bahwa masyarakat dapat menyampaikan pengaduan atas dugaan penyimpangan aparatur sipil negara kepada APIP dan/atau APH, selanjutnya APIP wajib melakukan pemeriksaan atas pengaduan tersebut, begitupun APH melakukan pemeriksaan atas pengaduan masyarakat setelah terlebih dahulu berkoordinasi dengan APIP.

Implementasi aturan ini dibuktikan adanya perjanjian kerja sama antara Kementerian Dalam Negeri Republik Indonesia dengan Kejaksaan Republik Indonesia dan Kepolisian Negara Republik Indonesia tentang Koordinasi Aparat Pengawas Internal Pemerintahan dengan Aparat Penegak Hukum dalam Penanganan Laporan atau Pengaduan Masyarakat yang Berindikasi Tindak Pidana Korupsi pada Penyelenggaraan Pemerintah Daerah. Tujuannya memperkuat sinergitas kerjasama diantara para pihak dalam koordinasi Tipikor pada penyelenggaraan pemerintah daerah guna terwujudnya penyelenggaraan pemerintah daerah yang efektif efisien dan akuntabel dalam rangka mewujudkan tujuan otonomi daerah. Skema pelaksanaan kerjasama disepakati bahwa tukar menukar data dan/atau informasi dilakukan pada tahap setelah terbitnya laporan hasil pemeriksaan oleh APIP kepada pihak APH.

Arti penting dalam perjanjian kerja sama tersebut antara APIP dan APH sama-sama berwenang dan berkewajiban menindaklanjuti pengaduan sesuai

${ }^{19}$ Angelica et al, "Analisis Sistem Pengendalian Internal pada Proses Pemberian Kredit di PT. Bank Rakyat Indonesia. Tbk Cabang Batam,” Jurnal Measuremen 3, no. 2 (2016): 140. 
kewenangannya. Adanya perjanjian kerjasama tersebut, APIP dapat menindaklanjuti laporan atau pengaduan masyarakat yang diterima secara langsung melalui pemeriksaan investigatif untuk menentukan laporan atau pengaduan tersebut berindikasi kesalahan administrasi atau pidana. Jika ditemukan indikasi tindak pidana korupsi, APIP menyerahkan kepada APH guna dilakukan proses penyelidikan. Adapun jika APH dalam hal menemukan kesalahan administrasi dalam penanganan laporan atau pengaduan masyarakat maka informasi tersebut diserahkan kepada APIP.

Sebagai kriteria kesalahan administrasi adalah tidak terdapat kerugian keuangan negara/daerah, terdapat kerugian keuangan negara/daerah dan telah diproses melalui tuntutan ganti rugi atau tuntutan perbendaharaan paling lambat 60 (enam puluh) hari sejak laporan hasil pemeriksaan APIP atau Badan Pemeriksa Keuangan (BPK) diterima oleh pejabat atau telah ditindaklanjuti dan dinyatakan selesai oleh APIP atau BPK, merupakan bagian dari diskresi, sepanjang terpenuhi tujuan dan syarat-syarat digunakan diskresi atau merupakan penyelenggaraan administrasi pemerintahan sepanjang sesuai dengan asas umum pemerintahan yang baik. Subyek yang dilaporkan atau diadukan masyarakat meliputi penyelenggara pemerintahan daerah yang masih aktif yaitu kepala daerah dan wakil kepala daerah, pimpinan dan anggota DPRD, ASN pemerintah daerah, kepala desa dan perangkat desa.

Kembali kepada kedudukan APIP menurut aturan dalam Perpres No 16 Tahun 2018, domain APIP adalah pengawasan. Kegiatan pengawasan awal tersebut adalah pemeriksaan investigatif oleh APIP. Jika dalam pemeriksaan terindikasi adanya tindak pidana tipikor di pengadaan barang/jasa pemerintah maka APIP menyerahkan proses berikutnya kepada APH. Sedangkan domain APH adalah menindaklanjuti hasil pemeriksaan/audit investigasi dari APIP yang berindikasi awal tindak pidana korupsi tersebut melalui proses penyelidikan.

\section{Kendala Dan Solusi Atas Kedudukan Aparat Pengawasan Internal Pemerintah (APIP) Dalam Pengawasan Pengadaan Barang/Jasa Pemerintah Berdasarkan Pasal 77 Perpres No. 16 Tahun 2018}

Hukum akan bergerak jauh lebih lambat daripada dinamika masyarakat Indonesia. Bahkan yang lebih buruk lagi, pelaksanaan pemerintahan akan bergerak kaku dan cenderung represif. Demikian juga dengan penerapan konsep rule of law secara murni, pengendalian negara pada masyarakat akan sangat lemah, sebab masyarakat Indonesia yang sangat plural dan tersebar. ${ }^{20}$

Penulisan artikel ini menggunakan teori sistem hukum dari Lawrence M. Friedman yang terdiri dari legal substance (substansi hukum), legal structure (struktur hukum) dan legal culture (budaya hukum) untuk menjelaskan kendala dan solusi atas kedudukan APIP dalam pengawasan pengadaan barang/ jasa pemerintah

${ }^{20}$ Hidayat, Arif dan Arifin, Zaenal, "Politik Hukum Legislasi Sebagai Socio-Equilibrium di Indonesia" Jurnal Ius Constituendum 4, no. 2 (2019): 150. 
berdasarkan Perpres No 16 Tahun 2018. Dengan menggunakan perspektif sistem hukum tersebut, akan menjadikan pembeda dengan penelitian yang sudah ada sebelumnya. Seperti yang sudah dibahas sebelumnya, peran dan fungsi APIP dalam pengawasan pengadaan barang/ jasa pemerintah selama ini terumuskan dalam beberapa tugas utama dalam sebuah manajemen risiko.

Hasil kajian pencegahan korupsi pada pengadaan barang dan jasa pemerintah (PBJ) oleh Komisi Pemberantasan Korupsi (KPK) menunjukkan gambaran sebagai berikut:

1. Perkara Korupsi PBJ dominan ada 142 perkara dari 468 perkara. Modus operandi penyuapan boleh jadi terkait dengan perkara PBJ. Sementara itu jumlah pengaduan masyarakat terkait PBJ ke KPK hingga 2015 sekitar 12.693 pengaduan. Adapun kerugian keuangan negara hampir Rp. 1 triliun dari kasus pengadaan barang dan jasa.

2. Dalam aspek ketidakefektifan anggaran, terjadi fakta bahwa Rp. 96,09 miliar pada kementerian atau lembaga dan pemda. Sebaran kasusnya Rp 69,17 miliar dalam 2 objek pemeriksaan di 11 kementrian/lembaga. Sedangkan Rp 26,92 miliar dalam 6 objek pemeriksaan di 2 provinsi dan 14 kabupaten/kota. Faktor penyebabnya adalah: pengadaan barang yang belum/ tidak dapat dimanfaatkan, penggunaan tidak tepat sasaran/tidak sesuai peruntukan, pemanfaatan barang/jasa tidak sesuai rencana yang ditetapkan.

3. Persekongkolan tender pengadaan barang dan jasa periode $2006-2012$, terjadi 97 perkara yang sudah diputus ditemukan bahwa total proyek Rp 12,35 triliun yang merupakan proyek gabungan dari proyek swasta, BUMN, APBN, dan APBD. Yang terbukti dari persekongkolan sebesar Rp 8,6 triliun.

Sehubungan dengan problematika korupsi dalam pengadaan barang/jasa pemerintah, maka akar masalah dari pemetaan KPK diperoleh paparan penting berkaitan dengan fungsi pengawasan (APIP) sebagai berikut:

1. Tindak pidana korupsi pengadaan barang/jasa pemerintah pada aspek pengawasan dan pertanggungjawaban, deskripsi fakta hukumnya menerangkan bahwa terjadi delik penyuapan kepada auditor (BPKP maupun BPK) dan penegak hukum. Subyek auditor dengan niat menghilangkan hasil audit, sedangkan kepada penegak hukum berupa meringankan hukuman tindak pidana.

2. Permasalahan pengadaan barang/jasa pemerintah, diketahui setelah adanya kasus kerugian dan atau tindak pidana. Sehingga dapat dikatakan bahwa belum adanya strategi preventif dari APIP berakibat muncul masalah secara reaktif, yaitu terlambat diketahui setelah adanya kasus tindak pidana atau kerugian keuangan negara.

Gambaran permasalahan sektor pengadaan barang/jasa pemerintah tersebut pada pembahasan berikutnya dapat diskemakan sebagai berikut: 
1) Kendala yang dihadapi APIP dalam fungsi pengawasan pengadaan barang dan jasa pemerintah

2) Pembagian ranah atau domain kendala ditinjau dari legal substance (substansi hukum), legal structure (struktur hukum) dan legal culture (kultur hukum) yang diadaptasi dari teori sistem hukumnya Lawrence M. Friedman.

3) Perumusan solusi dari ketiga ranah sub sistem pada no 2 berbasis kepada peran APIP saat ini dan di masa yang akan datang dalam fungsi pengawasan pengadaan barang/jasa sebagaimana diatur dalam Perpres No 16/2018.

Kendala utama yang dihadapi APIP dalam fungsi pengawasan pengadaan barang dan jasa pemerintah adalah tidak adanya pengaturan legislasi mengenai mekanisme pengawasan pengadaan barang/jasa selain melalui pengaduan masyarakat, sehingga peran APIP dalam pencegahan korupsi pengadaan barang/jasa tidak efektif. Secara substansi hukum memang APIP tidak memungkinkan untuk melaksanakan pengawasan dari hulu hingga hilir dalam pelaksanaan pengadaan barang/jasa. Di sisi lain independensi dan kompetensi APIP juga menjadi kendala tersendiri. Secara kelembagaan APIP berada dibawah kepala kementerian/lembaga/daerah sehingga dalam prakteknya APIP sering terkendala pragmatisme budaya kerja. Belum lagi kompetensi APIP dalam memilah perkara yang diperiksa termasuk domain hukum administrasi atau hukum pidana.

Problematika yang lain dalam pencegahan tipikor pada sektor pengadaan barang/ jasa pemerintah adalah terkait pengaturan penerimaan pengaduan masyarakat pada Pasal 77 Perpres 16 Tahun 2018 yakni tidak adanya ruang bagi APH dalam pengawasan pengadaan barang/jasa pemerintah sebagaimana telah diuraikan pada bab sebelumnya. Sistem pengaduan masyarakat telah menjadi rumusan peraturan perundang-undangan sejak lama. Adanya kewajiban APH meneruskan pengaduan masyarakat kepada APH tanpa menindaklanjuti pengaduan tersebut sesuai kewenangan APH, berpendapat bahwa bentuk intervensi kewenangan yang dimiliki APH. Pemetaan kendala kedudukan APIP dalam ranah atau domain:

a) Legal Substance (Substansi Hukum)

APIP dapat dianalogikan sebagai "polisi"nya pengadaan barang/jasa pemerintah. Meskipun tidak memiliki sejumlah kewenangan seperti Aparat Penegak Hukum dalam domain yudikatif, setidak-tidaknya peran APIP mirip jika tidak dapat dikatakan sama dengan APH. APIP di domain pemerintahan atau eksekutif, sedangkan APH di domain yudikatif atau penegakan hukum. Perpres 16 Tahun 2018 memuat aturan mengenai pengawasan pengadaan barang/jasa pada Pasal 76 yakni kewajiban oleh menteri/pimpinan lembaga/ kepala daerah melalui APIP yang dilakukan melalui kegiatan audit, review, pemantauan, evaluasi, dan/atau 
penyelenggaraan whistle blowing system, sejak perencanaan, persiapan, pemilihan penyedia, pelaksanaan kontrak, dan serah terima pekerjaan.

Sebagai sistem yang terintegrasi dari pusat hingga daerah, dirasa perlu adanya "dirigen" yang sama yang mengoperasionalisasi fungsi pengawasan terhadap pengadaan barang/jasa. APH tidak diberi kewenangan menindaklanjuti pengaduan masyarakat atas pengadaan barang/jasa melainkan harus meneruskan pengaduan tersebut kepada APIP untuk ditindaklanjuti. Menindaklanjuti laporan atau pengaduan masyarakat merupakan kewenangan sekaligus kewajiban APH dalam melayani masyarakat. Adanya kewajiban APH meneruskan pengaduan masyarakat kepada APH tanpa menindaklanjuti pengaduan tersebut sesuai kewenangan APH, merupakan bentuk intervensi kewenangan yang dimiliki APH.

b) Legal Structure:

Perspektif legal structure menerangkan bahwa kedudukan APIP belum cukup stabil dalam dua hal. Kedua budaya intervensi pejabat yang lebih tinggi dalam fungsi kerja APIP. Posisi struktural APIP yang berada dibawah kepala kementerian/lembaga/daerah, berdampak terhadap budaya kerja dan sistem manajemen ketidakberpihakan (imparsialitas) fungsi APIP dalam tubuh pemerintahan baik pusat maupun daerah. Dalam prakteknya APIP sering dipertanyakan independensinya.

c) Legal Culture: ancaman mutasi, buangan dan titipan

Lensa budaya hukum dalam menyoal kedudukan APIP terkendala oleh praktek kerja yang penuh dengan ancaman mutasi jika tidak mematuhi the silent culture pemerintahan. Selain itu posisi APIP seringkali diisi oleh staf "buangan" dari instansi lain dan staf titipan yang diragukan kompetensinya.

Sehubungan dengan problematika tersebut, maka solusi atas kendala kedudukan APIP saat ini dan yang akan datang sebagai berikut:

a) Dimensi Legal Substance

Disisi lain juga aturan yang tidak memberi ruang bagi APH dalam pengawasan pengadaan barang/jasa akan menyulitkan kolaborasi antara APIP dan APH yang selama ini sudah dibangun dalam berbagai aturan perundang-undangan yang sudah ada. Pada akhirnya pencegahan korupsi dari sektor pengadaan/barang jasa tidak akan pernah tercapai, sebagaimana dalam pemetaan BPKP, deskriptor pengawasan menduduki skala tertinggi dalam hal dampak dan frekuensi pada manajemen risiko anggaran, memiliki ruh norma dalam mengikuti perkembangan sosial, politik, budaya dan IPTEK.

Maka ke depan perlu ada revisi Perpres 16 Tahun 2018 tentang pengadaan barang/jasa yang memuat; pertama, adanya perlibatan APIP 
dalam setiap proses pengadaan barang/jasa dalam rangka pengawasan, tidak hanya ketika ada pengaduan masyarakat atau setidak-tidaknya ada akses bagi APIP dalam melakukan pemeriksaan pada laporan hasil pengadaan barang/jasa pada setiap tahapannya. Kedua, hilangkan aturan yang membatasi ruang bagi APH dalam melaksanakan tugasnya untuk menindaklanjuti atas pengaduan masyarakat tentang dugaan tipikor pada pengadaan barang/jasa pemerintah, karena tidak selamanya tindak pidana korupsi pada pengadaan barang/jasa adalah menyangkut kerugian keuangan Negara dalam ranah administrasi, tetapi memungkinkan juga suap, gratifikasi dan pemerasan di dalamnya.

b) Dimensi Legal Structure

Perspektif sebelumnya menjelaskan bahwa kedudukan APIP dalam pengawasan pengadaan barang/jasa pemerintah saat ini mengalami defisit norma hukum dan butuh penguatan dalam kebijakan legislasi berupa revisi atas Perpres 16 Tahun 2018. Pertama, dalam sisi kelembagaan. Hal ini penting guna menghadang budaya intervensi dan konflik kepentingan dalam pengadaan barang dan jasa. Untuk itu perlu adanya metode lelang jabatan dalam memilih dan memilah staf atau pimpinan APIP dibarengi dengan sistem remunerasi yang "tidak biasa". Sehingga dengan adanya dua gagasan di atas timbul harapan bahwa potensi korupsi melalui adanya kewenangan Diskresi plus kekuasaan Monopoli minus Akuntabilitas $(C=\{D+M\}-A)$ dapat dibenahi dengan tata kerja preemtif dan preventif.

c) Dimensi Legal Culture

Pada perspektif ini usulan ke depan dalam membangun budaya hukum di ekosistem APIP, berisi tentang poin :

\section{Pengawasan Bersifat Proaktif}

Guna meningkatkan dan mereformasi di tubuh APIP perlu perubahan paradigma bekerja pada fungsi pengawasan yaitu proaktivitas. Istilah ini tidak hanya menekankan sisi inisiatif, lebih dari itu pendekatan proaktivitas hanya bisa dilakukan oleh individu yang bebas memilih. Mengingat tumbuh kembangnya ekosistem ini berkaitan dengan kemandirian dan independensi maka struktur organisasi yang mewadahinya pun butuh struktur kerja yang bebas dan mandiri.

2. Menciptakan Early Warning System

Proaktif sebagai paradigma kerja lebih menekankan sisi budaya kerja preemtif (kemampuan menekan potensi kecurangan/fraud maupun indikasi tindak pidana dalam bentuk dalam "dataran" potensi. Budaya preventif lebih menekankan kepada pencegahan potensi kecurangan/fraud maupun tindak pidana karena pelanggaran dan kejahatan masih tetap di area ambang. 
Early warning system (sistem deteksi dini) hanya efektif berjalan jika tidak hanya mengandalkan unsur pengawasan dari eksternal APIP melainkan perlunya deteksi dini dari infiltrasi APIP pada setiap proses pengadaan barang/jasa, bukan untuk mengintervensi pelaksanaan pengadaan melainkan lebih pada pengawasan dan pencegahan kecurangan/fraud.

Kolaborasi APIP dan APH juga akan sangat efektif dalam rangka deteksi dini/early warning system pencegahan dan pemberantasan korupsi dari sektor pengadaan barang/jasa pemerintah.

3. Budaya Terukur dan Achievement Orientation Auditor melalui Indeks Internal Audit Capability Model (IACM)

Budaya kerja yang terukur dan berorientasi pada prestasi merupakan dorongan utama melakukan transformasi manajemen perubahan (change management) dalam sebuah organisasi. Hal ini perlu diimbangi dengan sistem remunerasi yang berbeda sebagai penyeimbang prestasi kerja fungsi pengawasan.

Penjelasan di atas melengkapi penelitian terdahulu yang pernah dilakukan oleh Lumempouw et al (2021) yang menyimpulkan bahwa permasalahan yang dihadapi APIP dalam mencegah dan mendeteksi kecurangan biaya perjalanan dinas, yaitu: 1) keterbatasan waktu, sumber daya manusia. dan anggaran; 2) Kurangnya partisipasi auditee dalam audit; 3) Kurangnya pemahaman tentang audit berbasis risiko; dan 4) Unit konsultasi belum terbentuk. Kemudian dalam artikel Marliani et al (2018) yang menyimpulkan bahwa metode, implementasi penguatan peran APIP juga memiliki beberapa kendala diantaranya, kompetensi sumber daya manusia para auditor, jumlah anggaran relatif kecil, lemahnya independensi, objekvitas auditor masih kurang, dan komitmen dari stakeholder belum maksimal. Pembahasan problematika dan solusi APIP ke depan secara ringkas dapat dihimpun sebagai berikut :

Kedudukan APIP dalam pengadaan barang/jasa pemerintah sebagaimana diatur dalam Perpres No 16/2018, pada aspek legal substance (substansi hukum) masih adanya kelemahan yuridis dalam hal tidak adanya aturan yang memberi ruang bagi APIP dalam melaksanakan tugas pengawasan dalam setiap proses pengadaan barang/jasa, dan juga aturan yang membatasi ruang bagi APH dalam menindaklanjuti pengaduan masyarakat tentang adanya penyimpangan pengadaan barang/jasa, akan menyulitkan kolaborasi antara APIP dan APH yang selama ini sudah dibangun dalam berbagai aturan perundang-undangan yang sudah ada. Pada Akhirnya pencegahan korupsi dari sektor pengadaan/barang jasa tidak akan pernah tercapai.

Ke depan perlu ada revisi Perpres 16 Tahun 2018 tentang pengadaan barang/jasa yang memuat; pertama, adanya perlibatan APIP dalam setiap proses 
pengadaan barang/jasa dalam rangka pengawasan, tidak hanya ketika ada pengaduan masyarakat atau setidak-tidaknya ada akses bagi APIP dalam melakukan pemeriksaan pada laporan hasil pengadaan barang/jasa pada setiap tahapannya. Kedua, hilangkan aturan yang membatasi ruang bagi APH dalam melaksanakan tugasnya untuk menindaklanjuti atas pengaduan masyarakat tentang dugaan Tipikor pada pengadaan barang/jasa pemerintah.

Fungsi APIP (kewenangan/kekuasaan eksekutif) perlu koordinasi dengan Aparat Penegak Hukum (APH, kekuasaan/ kewenangan yudikatif) dalam menindaklanjuti indikasi kecurangan/ penyimpangan anggaran yang terindikasi pidana. Sedangkan pada kenyataan lainnya, APIP masih terkendala independensi dan imparsialitas (ketidakbeperpihakan). Dampaknya kendala koordinasi dalam kegiatan Pulbaket (pengumpulan bukti dan keterangan) bagi penyidik. Akibatnya indikasi tindak pidana dapat hilang karena ketiadaan barang bukti yang berkualitas.

Pada aspek legal structure (struktur hukum), APIP terkendala dalam struktur organisasi yang penuh dengan intervensi serta kurang adanya kemandirian serta kebebasan dalam menjalankan fungsi pengawasan. Sehingga peran sentral sebagai katalisator tata pemerintahan yang baik (good governance) potensinya belum tersalur secara baik. Ke depan perlu direvitalisasi dalam satu top leader pengawasan, satu komando dan berparadigma bukan menemukan kesalahan saja namun mitra strategis dan partner kerja produktif bagi stake holder pengadaan barang dan jasa pemerintah. Kendala pada sub sistem hukum sebelumnya (substansi dan struktur hukum) berimplikasi kepada management perubahan baik dalam sistem kerja maupun individu anggota/ staf/ pimpinan (SDM) APIP. Sistem kerja yang terukur dan orientasi prestasi, menjadi keniscayaan dalam mengadaptasi perubahan hukum baik dalam kualitas maupun kuantitas jenis penyimpangan, kecurangan maupun yang terindikasi tindak pidana korupsi.

\section{E. PENUTUP}

Berdasarkan rumusan masalah dan pembahasan dapat disimpulkan, kedudukan APIP dalam Perpres Nomor 16 Tahun 2018, diatur pada subbab Pengaduan. Kewenangan APIP didefinisikan sebagai menerima pengaduan baik dari masyarakat maupun APH. APIP berwenang menindaklanjuti pengaduan tersebut, dengan syarat memenuhi aturan bukti. Terakhir, melaporkan hasil tindak lanjut tersebut kepada kepala kementerian/lembaga/pemerintah daerah. Adapun kendala dan solusi kedudukan APIP yang diatur dalam Perpres Nomor 16 Tahun 2018 dapat dilihat dari 3 dimensi sub sistem hukum; pertama, secara legal substance, masih adanya kelemahan yuridis dalam hal tidak adanya aturan yang memberi ruang bagi APIP melaksanakan tugas pengawasan, dan juga aturan yang membatasi ruang bagi APH menindaklanjuti pengaduan masyarakat. Perlu adanya revisi Perpres 16 Tahun 2018 yang memuat perlibatan APIP dalam setiap proses pengadaan barang/jasa, tidak hanya ketika ada pengaduan masyarakat atau setidak- 
tidaknya ada akses bagi APIP dalam melakukan pemeriksaan pada laporan hasil pengadaan barang/jasa pada setiap tahapannya. Kedua, secara legal structure, terindentifikasi kendala pada dua aspek, yaitu struktur organisasi APIP dalam pemerintahan dan sistem kerja (sistem pengembangan karier). Struktur organisasi APIP yang secara kelembagaan berada di bawah kepala kementerian/lembaga/pemerintahan berdampak pada fungsi kerja yang lemah secara sistem ketidakberpihakan (imparsialitas). Perlu semacam komite audit sebagai wadah kelembagaan yang independen dan merdeka "mirip" mitra kerja mereka di kekuasaan yudikatif yaitu APH. Sistem pengembangan karier dengan motivasi mutasi karena adanya tekanan atasan perlu dihindari ke depan sebagai jawaban atas prestasi auditor yang kompeten dan berintegritas. Dan ketiga, secara legal culture, kedudukan APIP menyisakan problematika paradigma kerja individu dan organisasi yang terkesan reaktif. Untuk itu ke depan APIP perlu revitalisasi pola pikir dengan paradigma proaktivitas, sebagai katalisator tata pemerintahan yang tidak hanya menemukan "bukti penyimpangan/kecurangan" lebih dari itu membutuhkan mitra kerja yang mampu merumuskan tindakan preemtif dan preventif sebelum adanya indikasi tindak pidana korupsi pengadaan barang/jasa pemerintah.

\section{DAFTAR PUSTAKA}

Ahmad, Rijali, “Analisis Data Kualitatif,” Jurnal Alhadharah 17, no. 33 (2018): 81-95.

Alfianto, Dwi, "Peran Aparat Pengawas Intern Pemerintah (APIP) untuk Mewujudkan Good Governance dalam Pencegahan Tindak Pidana Korupsi di Bidang Penyediaan Barang dan Jasa," Jurnal Hukum Pidana dan Pembangunan Hukum 1, no. 2 (2019): 1-9.

Angelica et al, "Analisis Sistem Pengendalian Internal pada Proses Pemberian Kredit di PT. Bank Rakyat Indonesia. Tbk Cabang Batam," Jurnal Measuremen 3, no. 2 (2016): 132-153.

Arifin, Zaenal, "Tindak Pidana Korupsi Pengadaan barang dan Jasa Pemerintah" Jurnal Responsif, no. 5 (2017): 55.

Bajuri, Diding, "Analisis Kualitas Pelayanan Publik Perangkat Desa Pagandon Kecamatan Kadipaten Kabupaten Majalengka," Jurnal Ilmu Administrasi Negara 4, no. 1 (2013): 145-170.

Benuf, Kornelius, dan Azhar, Muhamad, "Metodologi Penelitian Hukum sebagai Instrumen Mengurai Permasalahan Hukum Kontemporer," Jurnal Gema Keadilan 7, no. 1 (2020): 20-33.

Hidayat, Arif dan Arifin, Zaenal, "Politik Hukum Legislasi Sebagai SocioEquilibrium di Indonesia" Jurnal Ius Constituendum, no. 2 (2019): 150.

Laporan Tahunan Komisi Pemberantasan Korupsi, 2018.

Lumempouw, Eliska Gricy et al, "Analisis Peran Aparat Pengawas Internal Pemerintah (Apip) dalam Pencegahan dan Pendeteksian Fraud Biaya Perjalanan Dinas (Studi Kasus Pada Inspektorat Daerah Provinsi Sulawesi 
Utara)," Jurnal Riset Akuntansi dan Auditing “Goodwill” 12, no. 2 (2021): 252-263.

Marliani et al, "Evaluasi Efektivitas Penguatan Peran Aparat Pengawasan Intern Pemerintah dalam Paradigma Baru (Studi Kasus pada Salah Satu Inspektorat di Aceh)," Jurnal Perspektif Ekonomi Darussalam 4, no. 1 (2018): 95-108.

Muhammad Iqbal, "Pengaruh Pelaksanaan E Katalog dalam Pengadaan Barang/Jasa Pemerintah terhadap UMKM," Jurnal USM Law Review 3, no 1 (2020): 79.

Pasaribu, Pramella Yunidar dan Briando, Bobby, "Internalisasi Nilai-Nilai Pancasila dalam Penyusunan Kode Etik Aparatur Pengawas Internal Pemerintah (APIP)," Jurnal Ilmiah Kebijakan Hukum 13, no. 2 (2019): 245264.

Peraturan Presiden Republik Indonesia Nomor 16 Tahun 2018 tentang Pengadaan Barang/Jasa Pemerintah.

Perjanjian Kerja Sama Kementrian Dalam Negeri, Kejaksaan Republik Indonesia, Kepolisian Negara Republik Indonesia tentang tentang Koordinasi Aparat Pengawas Internal Pemerintah (APIP) dengan Aparat Penegak Hukum (APH) Terkait Penanganan Laporan atau Pengaduan Masyarakat dalam Penyelenggaraan Pemerintahan Daerah.

Sari, Milya, "Penelitian Kepustakaan (Library Research) dalam Penelitian Pendidikan IPA," Jurnal Penelitian Bidang IPA dan Pendidikan IPA 6, no. 1 (2020): 41-53.

Sugiyono, "Metode Penelitian Kuantitatif Kualitatif dan $R \& D$ ", (Bandung: Alfabeta, 2009).

Yohanes Elieser, "Peran Aparat Pengawas Intern Pemerintah (APIP) dalam Penyelenggaraan Pemerintahan Daerah di Kabupaten Bulungan," Jurnal Paradigma 7, no. 2 (2018): 55-64.

Yuliana, "Dampak Pelaksanaan Hukuman Mati terhadap Kondisi Kejiwaan Terpidana Mati di Indonesia," Indonesian Journal Of Criminal Law Studies 1, no. 1 (2016): 45-54.

Yunus Nur Rohim, "Menciptakan Good and Clean Government Berbasis Syariah Islamiyah dalam Tatakelola Pemerintahan Republik Indonesia," Jurnal Nur El-Islam 3, no. 1 (2016): 143-175.

Zellatifanny, Cut Medika dan Mudjiyanto, Bambang, "Tipe Penelitian Deskripsi dalam Ilmu Komunikasi," Jurnal Diakom 1, no. 2 (2018): 83-90. 